\title{
The family involvement in different early childhood curricula and approaches in the world
}

\author{
Cansu Yıldız ${ }^{* a}$, Mine Canan Durmuşoğlu ${ }^{* * b}$ \\ ${ }^{a}$ Hacettepe University, Faculty of Education, Ankara/Turkey
}

Article Info

DOI: 10.31704/ijocis.2018.002

Article History:

Received 19 February 2018

Revised 21 May 2018

Accepted 23 May 2018

Online $\quad 30$ June 2018

\section{Keywords:}

Family involvement,

Early childhood,

Approaches,

Curricula and models.

Article Type:

Review

\begin{abstract}
Family involvement, an important element of effective early childhood education programs, is crucial for children's learning processes and development. With family involvement, while families have the opportunity of participating and contributing to their children's development and learning processes schools gain unique information about children's interests, needs and experiences. A positive cooperation to be developed between families and schools helps children to integrate home and school lives. The aim of this study is to present the current situation by reviewing the literature in terms of family involvement and discuss and compare the family involvement dimension of the Primary Years Program (PYP), Montessori, Reggio Emilia, Creative Curriculum and Te Whāriki programs, which are early childhood education programs and approaches around the world. For this purpose, a review study has been conducted.
\end{abstract}

\section{Dünyadaki farklı erken çocukluk eğitimi program ve yaklaşımlarında aile katılımı}

Makale Bilgisi

DOI: $10.31704 /$ ijocis.2018.002

Makale Geçmişi:

Geliş 19 Şubat 2018

Düzeltme 21 Mayıs 2018

Kabul 23 Mayıs 2018

Çevrimiçi 30 Haziran 2018

Anahtar Kelimeler:

Aile katılımı,

Erken çocukluk,

Yaklaşımlar,

Programlar ve modeller.

Makale Türü:

Derleme

\section{Öz}

Etkili erken çocukluk eğitimi programlarının önemli bir boyutu olan aile katılımı, çocukların öğrenme süreçleri ve gelişimleri için çok önemlidir. Aile katılımı ile okul, ailelerden çocukların ilgi, ihtiyaç ve deneyimlerine ilişkin eşsiz bilgiler kazanırken; aileler de çocuklarının gelişim ve öğrenme süreçlerine katılma ve katkıda bulunma fırsatına sahip olurlar. Aile ve okul arasında kurulacak olumlu işbirliği, çocuğun okul ve ev yaşantısını bütünleştirmesine yardımcı olur. Bu çalışmanın amacı dünyadaki erken çocukluk eğitim programı ve yaklaşımlarından illk Yıllar Programı (PYP), Montessori, Reggio Emilia, Yaratıcı Program (Creative Curriculum) ve Te Whāriki programlarının aile katılımı boyutunu literatür taraması yapıp inceleyerek mevcut durumunu ortaya koymaktır. Bu amaçtan hareketle derleme araştırması yapılmıştır.

\footnotetext{
* Author: yildizcansu90@gmail.com

Author: sendogdu@gmail.com
}

Orcid ID: https://orcid.org/0000-0003-0638-3826 Orcid ID: https://orcid.org/0000-0001-6777-9117 


\section{Introduction}

Following the change in the perception of child in the world, childhood has started to be seen as a separate developmental period. Scientific research into childhood and child education has pioneered the development of contemporary programs and approaches in education. Developed and developing countries have aimed to implement reforms at the system level, create modern institutions and develop new programs and models in education for more quality and effective education (Karip \& Köksal, 1996). Reynolds (1998) identified the eight principles of effective programs as follows: targeting children and families at high risk, initiating program involvement at early ages, providing comprehensive children development services, active and multidimensional parent involvement, child-centred program approach, teacher-children ratios, development of staff and teachers through continuous training, and systematic evaluation and monitoring.

Considering the entire life of an individual, some periods are considered as more critical than others in terms of development. The early years of life, called early childhood, are very important for the next life of the individual. Experiences offered the child in the early childhood will affect all aspects of the child's development in addition to his/her learning experience. The main objective of early childhood education is to develop and implement a quality education program considering the developmental characteristics and needs of children. Early childhood education, which cannot be left to coincidences, should be managed by serious, systematic and scientific organizations (Arı, 2003). In order to achieve the ideal objectives of pre-school education, studentcentred programs based on children's interests, needs, abilities and developmental characteristics should be designed besides-improving the physical infrastructures of the pre-school education institutions and qualities of their teachers and this program should incorporate family involvement into the education (Düşek \& Dönmez, 2012). To develop children's social-emotional skills, self-care skills, motor skills and cognitive and linguistic skills as a whole and to direct these skills towards their interests and abilities, family support is needed along with the quality pre-school education (Demirel, 2005). A quality early childhood program cannot yield intended results without family involvement. Morrison (1978) defined family involvement as a process which will eventually catalyse the potentials of families to explore family strengths and skills and to use them for the benefit of both themselves and their children (cited in Erkan, 2015).

The studies regarding family involvement suggest that children who have effective communication and cooperation with their parents and teachers are academically more successful in school life, can easily adapt to the school and show positive behaviours and attitudes more frequently compared to other children (Epstein, 2011; Henderson, Mapp, Johnson \& Davies, 2007; Sheldon, 2003). Family involvement studies also contribute to early literacy, early improvement of mathematical skills and social-emotional development of the children (Van Voorhis, Maier, Epstein, Lloyd \& Leung, 2013). Marcon (1999), who conducted a study on a group of fouryear-old children continuing in pre-school education from low-income families, stated that family involvement develops children's expressive language skills, academic skills, and playing behaviours positively. In a study conducted by Rimm-Kaufman, Pianta, Cox and Bradley (2003) based on teacher reports about 223 children, it was found that children whose families were participating in the education were more prepared for school than their peers, achieved higher success in language and mathematics and interacted with their friends more often. Studies show that family involvement significantly contributes to all aspects of children development.

Temel, Aksoy and Kurtulmuş (2015) examined the family involvement studies in early childhood education in seven dimensions: family education activities, family communication activities, participation of parents in educational activities, individual interviews, home visits, participation of parents in management and decision making processes and family support program. Family education activities include educational meetings and conferences; family communication activities include phone calls, booklets, tape recordings, photos, announcement panels, newsletters, letters and correspondence, portfolio files, meetings, school visits, arrival and departure times, Internet and suggestions boxes. The participation of parents in school trips, materialmaking activities or daily activities such as language and music represents the participation dimension of parents in activities. Individual meetings cover providing information about the children's developmental tendencies, informing parents about children's strengths and weaknesses which should be supported and informing parents about special issues. With home visits, teachers have the opportunity to observe the home environment, home responsibilities and child-parent relationships of the child. In the involvement process of parents in management and decision-making processes, which is the final dimension, the opinions of the parents are consulted on new issues and those considered to be suitable are implemented (Temel et al. 2015). Early childhood programs and approaches around the world can give more importance to different dimensions of family involvement, or include different adaptations and implementations according to their philosophy, objectives and goals. 
Although there are studies analyzing early childhood programs and approaches individually in the literature (Aslan, 2005; Çamlıkaya, 2007; Güler \& Yaltırık, 2011; Inan, 2012; Korkmaz, 2005; Mutlu, Ergişi, Ayhan \& Aral, 2012; Oğuz \& Köksal Akyol, 2006; Weiss, 2013), there are also a few studies that examined the approaches together. The study conducted by Tuncer (2015), examined Open Education, Waldorf, Montessori, Reggio Emilia, Primary Years Program, High Scope and Head Start programs and approaches in terms of their plans and practices, the roles of teachers, features and materials of the pre-school education and compared them with MEB 2013 Preschool Education Program. Yaşar-Ekici (2015) analyzed Reggio Emilia, High Scope, Waldorf and Montessori approaches comparatively in terms of theoretical basis, the educational environment and the role of teacher.

As a result of literature review, it has been found that there are many studies carried out on the different dimensions of the approaches. However, these studies have not included family involvement. From this point forth, the dimension of family involvement in Primary Years Program (PYP), Montessori, Reggio Emilia, Creative Curriculum and Te Whāriki programs have been comprehensively analyzed and compared in this study. It is believed that the comparative analysis of family involvement dimensions of different early childhood programs and approaches will significantly contribute to the literature. Moreover, by explaining family involvement of different approaches in details will provide a guideline for pre-school teachers, researchers, program developers and policymakers to provide quality services for children and their families and will contribute to the development of quality pre-school education programs.

In this study, a literature review was conducted by examining the relevant national and international literature for the purpose of analyzing the family involvement aspects of the Primary Years Program, Montessori, Reggio Emilia, Te Whāriki and the Creative Curriculum which are among early childhood education programs and approaches. Fink (2009) defines literature review studies as the evaluation and synthesis of the existing sources and documents by researchers by using systematic and explicit methods. There are several types of review articles. The review article can identify a phenomenon, rearrange an existing theory, or create a new one. Regardless of the type of review, the objective is to organize, integrate and evaluate previous studies by scrutinizing the literature to clarify a specific problem or subject. Such articles do not follow a standard format as in research reports. It consists of introduction, body and conclusion sections instead of introduction, methodology, results and discussion parts. The introductory section should specify the basic structure and purpose of the article. The introduction is of great importance as it is supposed to attract readers' attention (Morrison, 2004; Weed, 1997).

\section{Family Involvement in Early Childhood Education Programs Abroad}

The literature review of the family involvement dimension of early childhood education programs and approaches examined in the study are as follows:

\section{Primary Years Program (PYP)}

The PYP, which was developed by the International Baccalaureate Organization (IBO) in Switzerland in 1968, defined the importance of family involvement as support of the family for the school in every aspect. In this program, students, parents, teachers, other school personnel and administration are the stakeholders of school community. Schools regularly contact with parents to inform them about the events in the school to encourage parental support (IBO, 2014). Parents are informed and participative in Primary Years Program. It is very important for families to know the system and develop similar approaches at home for the effectiveness of the program. A student who questions, analyzes and reaches a conclusion at school should take part in the decision-making process at home by demonstrating these skills; otherwise, his/her acquisitions cannot be transformed into behaviours and stay limited merely with activities at school. This objective of the program is to create family environments which, in general, have improved the ability to think together and the skills of reasoning in family life. The activities carried out by children are shared with their families during portfolio days (Çamlıkaya, 2007).

Parents support the learning process of students in Primary Years Program. It is important to inform parents about what happens in the class and school. Teachers can ask for evidence on the children's learning at home environment to help parents be informed about what happens in the school. Sharing the works of children throughout the year helps to improve the communication between children and families for the development of learning and acquisitions. Parents are invited to school to exchange opinions on the works of students, which gives them the message that their comments and opinions are valuable. Communication between teachers and parents can be in the form of written notes, telephone calls, meetings, and conferences. Conferences are held where children can talk about the research topics they chose. Parents get an idea about the learning process of 
their children by participating in such conferences. Additionally, the program organizes meetings for parents. Parents are informed about their children's learning process, needs and school curriculum in these meetings. The exhibitions organized at the end of the school year are an important indication of integration of students and parents into the program. The year-end exhibition is a product of a large collaboration. Parents contribute to the evaluation process with teachers and children through exhibitions (IBO, 2002).

\section{Montessori Approach}

Family involvement plays an important role in this approach developed by Maria Montessori in the early 20th-century in Italy. In order for children to fully benefit from Montessori education, it is important for parents to understand the purposes of pedagogy and to support their children's holistic development. The quality and level of cooperation with parents vary from country to country in this approach. For instance, parents are invited to schools to observe and contribute to their children's learning and development in the United Kingdom. Furthermore, parents contribute to the learning process of their children by providing teachers with some information about their activities at home (Isaacs, 2012). Many Montessori schools offer training programs to the families. In this approach, training programs based on the Montessori philosophy are developed and parental involvement programs in learning process are prepared for parents (Danişman, 2012). According to Villegas and Biwer (1987), family involvement in the program aims to facilitate the integration of different ages in the class, the development of academic skills, and to improve the positive attitudes of the families towards the school (cited by Temel \& Toran, 2017). The school regularly communicates with families about their children's academic, physical and social development within the scope of the program. This communication usually takes place in the form of family-teacher meetings and written reports (Korkmaz, 2005). Additionally, practitioners working with the young age group inform parents about the daily routines of their children such as sleeping patterns, dietary habits, toilet habits, and participation in activities on a daily basis (Isaacs, 2012). In order to create a positive school atmosphere, it is aimed to go beyond cooperative relationship with families to establish quality relationships between the school and families (Korkmaz, 2005). Strategies such as regular meetings, school journal, special days, family training programs, admissions of new families, open board meetings, yearbooks, and cooperation with family associations have been implemented during the studies conducted for this purpose.

\section{Reggio Emilia}

The Reggio Emilia approach, developed in Italy by Loris Malaguzzi after World War II, regards families as educational partners. Home and society should be recognized as important learning environments in children's lives. Coordination between teachers, parents, and children are highly valued and the concept of 'learning group' is considered as a very important aspect of the Reggio Emilia approach (Giudici, Rinaldi \& Krechevsky, 2001). Parents are children's first and constant educators. The collaboration between practitioners and parents in early childhood has a positive influence on children's development and learning. Rinaldi (1985) lists the opportunities of family involvement as class meetings, small group meetings, individual parent-teacher meetings, themed meetings, meetings with a specialist, study sessions, laboratory work, holidays and celebrations (cited by Şahin, 2017). Bennett (2001) states that parents can also participate in the training program by making various arrangements in the learning environment (planting trees in the garden, preparing materials for the class, etc.). According to the approach, there are important messages behind showing respect towards parents as partners. Parents can positively contribute to children's learning and development by providing permanent and comprehensive learning settings. Parents have the right to play a central role in deciding on the care and education of the child at all levels. Successful relationships between parents and teachers have beneficial and long-lasting effects on children's education. Teachers should pay attention to the information given by parents about their children. In the Reggio Emilia approach, "Parental Rights" concept defines what parents can expect from the school and vice versa. It also underlines that parents should be a part of the school structure, rather than only playing a limited role in a certain part of the school structure. The school is aware of its responsibility to show parents how they understand and evaluate the children (Thornton \& Brunton, 2009).

Teachers carefully listen to the words parents have chosen to describe their children, especially at the beginning of the program. This information given by parents will help to prepare the appropriate environment and support for the children in order to adapt to the educational environment and benefit efficiently from learning experiences. Parents and children attend the acquaintance meetings and acquire information about the school before the beginning of kindergarten. This approach expects teachers to pay attention to cultural 
differences and create a learning environment where all children can receive positive messages. Some parents may have difficulty in understanding the approach; in this case teachers should be aware of the fact that these parents may need more encouragement and support.

Teachers should inform parents about the layout of the classroom environment, what has been done in the learning environment and what happened that day. In this approach, documentation has an important role. Parents arriving at the end of the day to get their children will receive a diary that includes photos taken by the teacher throughout the day and recorded child comments. In this way, parents might begin to talk with their children about their activities in the kindergarten on that day. Moreover, portfolios or other products that children prepared individually or as a group are shown to parents on their arrival and departure times and these products are sent home at regular intervals (Edwards, 2002). In this approach, it was emphasized that by giving an ID card which includes photographs of the employees, the building plan, and typical day-trips to the parents, parents would feel like a part of the environment. Parents participate in group meetings with teachers, workshop trainers, and pedagogues to discuss and share ideas on projects and topics related to the class. Parents also play a role in the management of centres by participating in early childhood councils (Thornton \& Brunton, 2014).

\section{Creative Curriculum}

The Creative Curriculum was developed in the United States in 1979. According to this program, home and school are two important worlds of the child. Children interconnect these two worlds every day. If a positive and respectful communication is established between home and school, the child would feel safe. However, if the relation between the family and school are severed due to lack of interest, understanding or cooperation, the child will be negatively affected. A teacher who believes in the role of the family in children education and is aware of what the child can accomplish with family cooperation can establish a right partnership with the family. The Creative Curriculum has addressed five issues that are significant for teacher-parent cooperation. These are getting to know families, hosting families, communicating with families, establishing partnerships with families in child learning and guiding them when the families have difficulties. Within the scope of getting to know families, the program emphasizes the importance of understanding cultural differences of the families and differences that may affect school relations such as different family structures, differences in personality and characteristics of parents, differences in the education level of parents, socioeconomic status and health problems. It is underlined that getting to know family members is a prerequisite for the child's development and during this process family members should not be generalized or labelled.

According to the program, the initial communication with the family is crucial. The first meeting with the families provides the teacher with great benefits to recognize the parents and establish positive relationships. The first contact with family members may be in the form of a home visit or a meeting during the school register. To obtain information about the family during registration, the school may ask the family to fill out forms or might ask parents some questions during the meetings. It can be useful to identify families with special talents and interest during registration for better communication with children in the classes. Home visits are of paramount importance in the program. Parents feel more comfortable in their own environment than they do at school. Home visits at the beginning of the school year are the first step of connecting school and home for a child who doesn't have not any previous experience in school settings. The program underlines that teachers should inform the families before the visits to decide on the time together. Teachers should encourage parents to talk about themselves by asking questions and they should aim to get to know parents not to judge them. According to the program, hosting families is important to make parents feel a sense of belonging to the program. Introducing the setting and program created at school may cause parents to feel that they belong to the process and play a role in the program. The environment should carry positive messages. Teachers can create a pleasant environment to host the families. Post and suggestion boxes can be placed at the class entrances for each family. Reading sources can be recommended for parents. A notice board can be created to announce program events. When a child participates in a program for the first time, parents wonder what their children will learn. The "Parental Guide to Pre-school Education" is offered to parents in the Creative Curriculum. The content of this guide which describes the philosophy of the program and its aims for the child is briefly explained to the parents and they are asked to read it later. The families are invited to the class to share their interests, how they have spent the day, and the expectations of the first day of the school. However, "Letters to the Families" at the end of each session of the Creative Curriculum explains what the children will do, how the teacher supports the children, and how families can help this process at home.

Another important component of the family involvement dimension of the Creative Curriculum is communicating with families. The trust between teachers and parents develops over time and relies on 
experiences gained through a positive and respectful framework. Just as in other programs, teachers in the Creative Curriculum have the opportunity to communicate informally with parents during arrival and departure times every day. In addition to the informal communication, there are also official ways to communicate such as daily or weekly newsletters, telephone calls, e-mail, Internet, class website, appreciation notes, diaries and automatic telephone messaging systems. Furthermore, not only parents but other family members can also be included in the program. Grandparents can devote more time than parents, participate in a program by reading books, teaching games, and helping special activities in the class.

Parents can participate in the program by making various arrangements or additions to the learning centres. They can share their cultures (cooking events, presenting artistic objects, singing, storytelling, etc.), their professions or skills. Teachers organize meetings with parents to provide information and share programs. During the meetings, families express their evaluation on the program and contribute to the improvement of the program. The teacher also provides solutions to the families having various problems and being under stress. As a result, the families know that the sources of the program are open to them for the solution (Dodge, Colker \& Heroman, 2008).

\section{Te Whāriki}

The Te Whāriki program was developed in 1996 by the New Zealand Ministry of Education. Collaboration is a fundamental concept in the early childhood philosophy of New Zealand. Te Whāriki emphasizes the central position of parents. This program deems the family as one of the collaborators in early childhood education. It aims to expand children's knowledge by maintaining a strong connection between family, school and the environment (Zhanq, 2013). Te Whāriki's early childhood services include play-oriented and community-based kindergartens administered by both teachers and parents. According to Te Whāriki program, children learn and develop when their culture, their knowledge and the society they live in are internalized and when the adults in their lives support them by working together. It is important that teachers and parents develop meaningful relationships and respect each other's aspirations and expectations for the development of children. Children's learning and development are facilitated when culturally appropriate means of communication are used and when the parents, people, and society participated in the curriculum. In this program, cultural diversity and different family structures are respected. The teacher should have information about the families of the children in order to reflect these structures properly in the program.

How the family is treated is important for the success of children in their first years. Parents and students are welcomed. Activities such as a shared lunch, trips or outdoor activities enable parents and teachers to gather. It is essential for teachers to work closely with parents to support the transition of children to the school environment and to communicate regularly with parents about their children's changing interests, needs, and development. The program has a reference library where teachers can inform the parents about nutrition, physical activity and growth of their children. The portfolios, which include children's photographs, products, teacher observation records and children's learning stories-provides parents with opportunities both to get an idea about their children's learning process and to contribute to the process with their own observations and recommendations. When programs are planned, the needs and opinions of early childhood providers, teachers and parents are taken into consideration in order for children to receive quality education and services (New Zealand Ministry of Education, 1996).

\section{Discussion, Conclusion and Implications}

It is seen that family involvement in early childhood contributes to the child's overall development, supports the child's readiness for school, enhances positive behaviours, and contributes to the future academic success in the school (Epstein, 2011; Henderson et al. 2007; Rimm-Kaufman et al. 2003; Sheldon, 2003). Considering the significant benefits of family involvement for children; family involvement seems to be an important dimension of a successful and effective program. In general, although there are minor differences in the extent of family involvement depending on the philosophy and principles of the programs, it is seen that all the programs analyzed have considered family involvement as an important dimension of their programs. All programs include family involvement activities that will strengthen family-school communication and collaboration, such as family meetings, individual meetings and portfolios including photos of children, teacher's observation records, and children's learning stories. Although the objectives of the programs vary according to the approaches and philosophy of the programs, all programs accept the family as the first and most important educator of the child (Temel \& Toran, 2017).

The Primary Years Program emphasizes family's knowledge on the system and their comprehensive support for the school. According to the program, it is very important for families to have a good knowledge of the 
system and develop similar approaches at home for the effectiveness of the program. A student who questions, analyzes and reaches the conclusion at school takes part in the decision-making process at home by using these skills. Exhibitions, where children share their work at the end of the school year, are an important aspect of family involvement for the Primary Years Program (Çamlıkaya, 2007; IBO, 2002). According to the family involvement understanding of the Montessori program, contacting regularly with parents about the academic, physical and social development of children or their situation during the day is an important aspect in the program.

In the Montessori approach, informing families about the program facilitates the integration of different ages in the class and the development of academic skills and also develops positive attitudes in families towards the school. Montessori schools aims to establish quality relationships between school and family. Family involvement activities include regular meetings, school newspapers, special days, family training programs, new family admissions, open board meetings, annuals and cooperation with family associations (Danişman, 2012; Temel \& Toran 2017). In the Reggio Emilia approach, "Parental Rights" concept defines what parents can expect from the school and vice versa. It also underlines that parents should be a part of the school structure rather than playing a limited role in certain part of school structure. The approach underlines the importance of documentation. Through documentation, parents can have an idea of what their children are doing at school with a diary which includes photos taken by the teacher throughout the day and recorded children comments (Edwards, 2002; Thornton \& Brunton, 2014). The Creative Curriculum integrates families into education by using a variety of methods in order to enable parents to understand, evaluate and support their children's development. Families take responsibilities for providing materials for the program, sharing their cultures (cultural material, clothing, food, songs, stories, picture sharing, etc.), sharing their professional experience or skills, participating in an activity and designing a program (Dodge et al. 2008). The Te Whāriki program, as other programs, considers the family as one of the partners in early childhood education. According to Te Whāriki program, children learn and develop when their culture, their knowledge and the society they live in are internalized and when the adults in their lives support them by working together. In this program, cultural diversity and different family structures are respected (New Zealand Ministry of Education, 1996; Zhanq, 2013).

When the programs and approaches are evaluated together, it can be seen that the common features of Reggio Emilia and the Creative Curriculum are home visits, inviting the families and various arrangements of parents in the class to contribute to the learning process. While experience sharing and interactions with parents at school are emphasized in all approaches, the Reggio Emilia approach is a step forward compared to the other programs with its documentation system and the Primary Years Program stands out by its year-end exhibitions. The Primary Years Program and the Montessori approach underline the families' understanding of the program for the efficient implementation of the program. In terms of cultural differences, Reggio Emilia, the Creative Curriculum and Te Whāriki give importance to the acceptance of the cultural structures of the families by educators and the positive treatment towards the families in order to ensure children's highest level of development and progress.

When schools develop their own educational programs, the quality and efficiency of their programs will increase if they use different family involvement studies of early childhood education programs and approaches. In this context, all stakeholders should work in cooperation to develop a family involvement dimension of a quality preschool education program. Curriculum designers and educators need to analyze family involvement studies of different early childhood education programs and approaches in details and incorporate the suitable ones for their own culture, for children and for their families into their programs. Schools and educators should be provided with the necessary infrastructure and equipment. Legal regulations for the education policies of a country should be implemented by the decision makers and law makers of the education ministries of the countries. The development of early childhood education programs of good quality supported by the effective implementation of school, family and community cooperation should strengthen the educational policies of the countries. Early childhood education programs in the world should be considered within the cultural context of the children and the family. Effective family involvement in the program should be ensured and programs should be planned and implemented within the social policies achieving social inclusion. Quality family involvement activities result in raising children who are fair, responsible, happy, in good physical and mental health condition. Those children also have equal education opportunities. In this way healthy, happy and productive families are formed. These families also provide important contributions to the development and improvement of the society. 


\section{TÜRKÇE SÜRÜM}

\section{Giriş}

Dünyada çocuk algısının değişimi ile çocukluk ayrı bir gelişim dönemi olarak görülmeye başlanmıştır. Çocukluk dönemine ve çocuk eğitimine yönelik yapılan bilimsel araştırmalar, eğitimde çağdaş program ve yaklaşımların geliştirilmesine öncülük etmiştir. Gelişmiş ve gelişmekte olan ülkeler, daha kaliteli ve etkili bir eğitim için sistem düzeyinde reformlar gerçekleştirmeyi, modern kurumlar oluşturmayı ve eğitimde yeni program ve modeller geliştirmeyi hedeflemişlerdir (Karip \& Köksal, 1996). Reynolds (1998), etkili eğitim programlarının sekiz prensibini, yüksek risk altındaki çocuk ve aileleri hedefleme, programa katılımın erken yaşlarda başlatılması, çocuk gelişimi hizmetlerinin kapsamlı olarak sağlanması, aktif ve çok yönlü ebeveyn katııımı, çocuk merkezli program yaklaşımı, öğretmen çocuk oranları, personelin ve öğretmenlerin eğitimlerle düzenli gelişimi ve sistematik değerlendirme ve izleme olarak sıralamıştır.

Bireyin tüm yaşamı düşünüldüğünde bazı dönemlerin gelişimsel açıdan daha kritik dönemler olarak ele alındığı görülmektedir. Erken çocukluk dönemi olarak adlandırılan yaşamın ilk yılları, bireyin sonraki yaşamı için oldukça önemlidir. Erken çocukluk döneminde, çocuğa erken yaşlarda sunulacak deneyimler, çocuğun öğrenim hayatının yanında çocuğun gelişiminin tüm alanlarını da etkileyecektir. Erken çocukluk eğitiminde temel amaç, çocukların gelişim özelliklerini ve ihtiyaçlarını göz önünde bulundurarak kaliteli bir eğitim programının hazırlamak ve uygulamaktır. Erken çocukluk eğitimi, tesadüflere bırakılamayacak kadar ciddi, sistemli ve bilimsel bir organizasyon ile yönetilmelidir (Arı, 2003). Okul öncesi eğitimin ideal amaçlarının gerçekleştirilebilmesi için okul öncesi eğitim kurumunun fiziksel özellikleri ve öğretmen niteliği gibi boyutların yanında çocuğun ilgi, ihtiyaç, yetenek ve gelişim özelliklerine göre hazırlanmış, aileyi de eğitimin içine alan öğrenci merkezli bir program oluşturulmalıdır (Düşek \& Dönmez, 2012). Çocukların sosyal-duygusal becerilerinin, öz bakım becerilerinin, bilişsel ve dil becerilerinin, motor becerilerinin bir bütün halinde geliştirilerek, ilgi ve yetenekleri doğrultusunda yönlendirilebilmeleri için nitelikli bir okul öncesi eğitiminin yanında aile desteği de gereklidir (Demirel, 2005). Nitelikli bir erken çocukluk programı aile katılımı boyutu olmadan düşünülemez. Morrison (1978) aile katııımını, ailelerin güçlerini ve becerilerini keşfetmek ve onları, kendileri ve çocukları yararına kullanmak amacıyla potansiyellerini harekete geçirecek bir süreç olarak tanımlamıştır (Cited in. Erkan, 2015).

Aile katılımına ilişkin yapılan çalışmalar incelendiğinde, ebeveynleri ve öğretmenleri etkili iletişim kuran ve işbirliği sağlayan ailelerin çocuklarının okul yaşantısında akademik olarak daha başarılı oldukları, okula daha kolay uyum sağladıkları, olumlu davranış ve tutumları daha sık sergiledikleri görülmektedir (Epstein, 2011; Henderson, Mapp, Johnson \& Davies, 2007; Sheldon, 2003). Aile katılımı çalışmaları ayrıca, çocukların erken okuryazarlık, erken matematik becerileri ve sosyal duygusal gelişimlerine de katkıda bulunmaktadır (Van Voorhis, Maier, Epstein, Lloyd \& Leung, 2013). Marcon (1999) düşük gelirli ailelerden gelen ve okul öncesi eğitim kurumuna devam eden dört yaş çocukları ile yaptığı araştırmada, aile katılımının çocukların ifade edici dil becerilerini, akademik becerilerini, oyun davranışlarını olumlu yönde geliştirdiğini ifade etmiştir. RimmKaufman, Pianta, Cox ve Bradley (2003) tarafından gerçekleştirilen, 223 çocuğa ilişkin öğretmen raporlarına dayanan araştırmada, aile katıııı gösteren ailelerin çocuklarııı akranlarına göre daha yüksek okula hazır bulunuşluk becerilerine sahip oldukları, dil ve matematikte daha yüksek başarı elde ettikleri ve akranları ile daha sık etkileşim kurdukları belirtilmiştir. Yapılan araştırmalar, aile katıımı çalışmalarının çocuğun tüm gelişim alanlarına önemli katkıları olduğunu göstermektedir.

Erken çocukluk eğitiminde aile katılım çalışmalarını Temel, Aksoy ve Kurtulmuş (2015), aile eğitim etkinlikleri, aile iletişim etkinlikleri, ebeveynlerin eğitim etkinliklerine katılımı, bireysel görüşmeler, ev ziyaretleri, ebeveynin yönetim ve karar verme süreçlerine katılımı ve aile destek programı olmak üzere yedi boyutta ele almışlardır. Aile eğitim etkinlikleri içerisinde, eğitim toplantıları ve konferanslar; aile iletişim etkinlikleri içerisinde telefon görüşmeleri, kitapçıklar, teyp/video kayıtları, fotoğraflar, duyuru panoları, bültenler, mektup ve yazışmalar, gelişim dosyaları, toplantılar, okul ziyaretleri, geliş-gidiş zamanları, internet ve dilek kutuları yer almaktadır. Ebeveynlerin gezi, materyal yapımı gibi etkinliklere ya da dil ve müzik gibi günlük etkinliklere katılım göstermesi, ebeveynlerin etkinliklere katılımı boyutunu ifade etmektedir. Bireysel görüşme, çocuğun gelişim alanları ile ilgili bilgi verme, yetenekli olduğu ve desteklenmeye ihtiyaç olduğu düşünülen alanları ve ebeveynlerle paylaşma ve özel durumlarla ilgili aileye bilgi verme gibi konular içermektedir. Ev ziyaretleri ile öğretmen, çocuğun ev ortamı, evde aldığı sorumluluklar ve ebeveyn çocuk ilişkilerini gözlemleme fırsatı bulur. Son boyut olan ebeveynin yönetim ve karar verme süreçlerine katılımında ise yeni ortaya çıkan durumlarda ailelerin görüşleri alııı ve uygun olanlar uygulamaya geçirilir (Temel et al. 2015). Dünyada 
uygulanan erken çocukluk program ve yaklaşımları, aile katılımı boyutunda kendi felsefe, amaç ve hedeflerine göre bazı noktalara daha çok önem verebilir ya da farklı uyarlama ve uygulamalar içerebilir.

Alan yazına bakıldığında, erken çocukluk program ve yaklaşımlarını tek tek inceleyen çalışmalar yer alsa da (Aslan, 2005; Çamlıkaya, 2007; Güler \& Yaltırık, 2011; İnan, 2012; Korkmaz, 2005; Mutlu, Ergişi, Bütün Ayhan \& Aral, 2012; Oğuz \& Köksal Akyol, 2006; Weiss, 2013), bir arada ele alan az sayıda araştırmaya rastlanmıştır. Tuncer (2015) tarafından yapılan çalışmada erken çocukluk eğitimi program ve yaklaşımlarından; Açık Eğitim, Waldorf, Montessori, Reggio Emilia, illk Yıllar Programı, High Scope, Head Start programlarını amaçları, plan ve uygulamaları, öğretmenlerin rolleri, okul öncesi eğitim kurumunun özellikleri ve materyalleri açısından MEB 2013 programı ile karşılaştırılarak incelenmiştir. Yaşar-Ekici (2015), Reggio Emilia, High Scope, Waldorf \& Montessori yaklaşımlarını kuramsal temel, eğitim ortamı ve öğretmenin rolü açısından karşılaştırarak incelemiştir.

Alan yazın taraması sonucunda incelenen yaklaşımların farklı boyutlarıyla ilgili birçok çalışma yapıldığı görülmüştür. Ancak bu yaklaşımların aile katııımı boyutu ile ilgili çalışmalara rastlanmamıştır. Bu noktadan hareketle, yapılan çalışmada Illk Yıllar Programı (PYP), Montessori, Reggio Emilia, Yaratıcı Program (Creative Curriculum) ve Te Whāriki programlarının aile katılımı boyutu derinlemesine incelenmiş ve karşıllaştııılmıştır. Çalışmada, farkı erken çocukluk program ve yaklaşımlarının aile katılımı boyutlarının karşılaştırmalı olarak incelenmesinin alan yazına önemli bir katkı sağlayacağı düşünülmektedir. Ayrıca bu çalışma ile farklı yaklaşımlardaki aile katııımı çalışmalarının detaylıca tanıtılması çocuklara ve ailelerine nitelikli hizmet sunmak için okul öncesi eğitim öğretmenlerine, alan araştırmacılarına, program geliştirici ve politika yapıcılara yol gösterecek ve kaliteli okul öncesi eğitim programları geliştirmelerine katkı sağlayacaktır.

Çalışmada erken çocukluk eğitim program ve yaklaşımlarından IIlk Yıllar Programı, Montessori, Regio Emilia, Te Whāriki ve Yaratıcı Program'ın aile katııım boyutlarının incelenmesi amacıyla ilgili ulusal ve uluslararası alan yazın taranarak derleme türünde bir araştırma ortaya konulmuştur. Fink (2009) literatür tarama araştırmalarını, var olan alan kaynak ve belgelerin, araştırmacılar tarafından değerlendirilip ve sentezinin yapılması, sistemli ve açık bir yöntemin kullanıldığı araştırmalar olarak tanımlamıştır. Derleme niteliğindeki makalenin birkaç türü bulunmaktadır. Derleme makale bir fenomeni tanımlayabilir, var olan bir teoriyi yeniden düzenleyebilir ya da bir yenisini oluşturabilir. Derlemenin türü ne olursa olsun, amaç belirli bir problemi ya da konuyu açıklığa kavuşturmak için literatürün taranarak önceki çalışmaların düzenlemesi, bütünleştirilmesi ve değerlendirilmesidir. Bu tür makaleler araştırma raporlarındaki gibi standart bir format izlememektedir. Giriş, yöntem, sonuç ve tartışma bölümlerinin yerine, giriş, gelişme ve sonuç bölümlerinden oluşur. Giriş bölümünde temel yapı ile bu makalenin yazılma amacı belirtilmelidir. Okuyucunun ilgisinin çekilmesi açısından giriş bölümü son derece önemli bir bölümdür (Morrison, 2004; Weed, 1997).

\section{Yurt Dışındaki Erken Çocukluk Eğitim Programlarında Aile Katııımı}

Araştırmada incelenen erken çocukluk eğitimi programı ve yaklaşımlarının aile katılımı boyutuna ilişkin alan yazın aşağıda yer almaktadır.

\section{ilk Yıllar Programı (PYP)}

Uluslararası Bakalorya Organizasyonu (IBO) tarafından 1968 yılında İsviçre'de geliştirilen PYP'de aile katııımının önemi, ailenin okulu her anlamda desteklemesi olarak ifade edilmiştir. Programda okul topluluğu öğrencilerin, velilerin, öğretmenlerin, diğer okul personelinin, idarenin ve yönetim organının yer alabileceği okulun paydaşlarıdır. Ebeveyn desteğini teşvik etmek için okullar düzenli olarak ebeveynleri okuldaki olaylardan haberdar etmek için onlarla iletişim kurar (IBO, 2014). ilk Yıllar Programında, veliler bilgili ve katılımcıdırlar. Ailelerin sistemi tanımaları ve evde de benzer yaklaşımlar geliştirmeleri programın işleyişi açısından çok önemlidir. Okulda sorgulayan, analiz eden ve sonuca varan öğrenci, evde de bu becerileri göstererek karar alma süreçlerine dahil olmalıdır, aksi takdirde kazanımları davranışa dönüşemez ve okulda yapılan etkinlikler ile sınırı kalır. Programdaki bu amaç genel anlamda aile yaşantısında, birlikte düşünme, neden ve sonuçları değerlendirme becerisini geliştirmiş aile ortamları oluşturabilmeyi hedefler. Çocukların gerçekleştirdikleri çalışmalar gelişim dosyası günlerinde aileler ile paylaşılır (Çamlıkaya, 2007).

Illk Yıllar Program'ında veliler, öğrencilerin öğrenme süreçlerine destek sağlarlar. Sınıfta ve okulda neler yaşandığı hakkında velilerin bilgilendirilmesi önemlidir. Öğretmen, çocukların öğrenmelerine ilişkin ev ortamından bir kanıt isteyerek, velilerin okulda neler yapıldı̆̆ı ile ilgili bilgilenmesine yardımcı olabilir. Çocukların yıl içinde yaptıkları çalışmaların ailelerle paylaşılması, çocuklar ve aileler arasında öğrenme ve kazanımlardaki gelişim üzerine paylaşımlar yapılmasını sağlar. Veliler, öğrencilerin çalışmalarıyla ilgili görüş alışverişinde bulunmak üzere okula davet edilirler, bu şekilde onlara yorum ve düşüncelerinin değerli olduğu mesajı verilir. Öğretmen ve veliler arasındaki iletişim, yazılı notlar, telefon görüşmeleri, buluşma ve konferanslar 
yolu ile gerçekleşir. Programda çocukların seçtikleri araştırma konuları hakkında konuşacakları konferanslar düzenlenir. Veliler bu konferanslara katılarak, çocuklarının öğrenme süreçleri hakkında fikir sahibi olurlar. Bunun yanında programda velilere yönelik toplantılar düzenlenir. Veliler çocuklarının öğrenim durumları, ihtiyaçları ve okul programı hakkında bilgilendirilirler. Programda yılsonunda düzenlenen sergiler, öğrencilerin ve velilerin programla bütünleşmelerinin önemli bir göstergesidir. Yılsonu sergisi, geniş bir işbirliği ürünüdür. Sergiler aracılığıyla veliler değerlendirme sürecine dâhil olarak çocuklar ve öğretmenlerle birlikte değerlendirme sürecine katkıda bulunurlar (IBO, 2002).

\section{Montessori Yaklaşımı}

20. yüzyılın başlarında İtalya'da Dr. Maria Montessori tarafından geliştirilen yaklaşımda aile katılımı oldukça önemlidir. Çocukların Montessori eğitiminden tam olarak yararlanması için, ebeveynlerin pedagojinin amaçlarını anlamaları ve çocuklarının bütüncül gelişimlerini desteklemeleri önemlidir. Yaklaşımda, ebeveynlerle işbirliğinin niteliği ve düzeyi ülkeden ülkeye değişmektedir. Birleşik Krallık'ta ebeveynler çocuklarının öğrenme ve gelişimlerine katkıda bulunmak ve çocuklarını gözlemlemek için okullara davet edilmektedirler. Ayrıca aileler evde yaptıkları faaliyetlere ilişkin öğretmenlere bilgi sağlayarak çocuklarının öğrenme süreçlerine katkıda bulunmaktadırlar (Isaacs, 2012). Birçok Montessori okulunda ailelere eğitim programları sunulmaktadır. Yaklaşımda, Montessori felsefesine ilişkin bir eğitim programı düzenlenir ve ebeveynler için öğrenme sürecine katılım programı hazırlanır (Danişman, 2012). Villegas ve Biwer (1987) programdaki aile katılımının, sınıftaki farklı yaşların entegrasyonunun kolaylaştırımasını, akademik becerilerin gelişiminde kolaylıklar sağlanmasını, ailelerin okula karşı olumlu tutumlar geliştirilmesini amaçladığını ifade etmiştir (Cited in Temel \& Toran, 2017). Yaklaşımda okul çocukların akademik, fiziksel ve sosyal gelişimleri hakkında, ailelerle düzenli aralıklarla iletişim kurar. Bu genellikle aile-öğretmen görüşmelerini ve yazılı raporları içerir (Korkmaz, 2005). Ayrıca yaklaşımda küçük yaş grubunda görev alan uygulayıcılar, çocukların uyku düzeni, beslenmesi, tuvalet alışkanlığı ve çocuğun etkinliklere katılımı gibi günlük rutinleri sözlü ya da yazılı bir şekilde günlük olarak ebeveynlerle paylaşır (Isaacs, 2012). Pozitif bir okul atmosferi yaratmak amacıyla, ailelerle işbirliğinin ötesine geçmeye çalışılır ve okul-aile arasında nitelikli ilişkiler kurmak amaçlanır (Korkmaz, 2005). Bu amaçla yapılan çalışmalarda düzenli toplantılar, okul gazetesi, özel günler, aile eğitim programları, yeni aile kabulleri, açık yönetim kurulu toplantıları, yılıklar, aile dernekleri ile işbirliği gibi stratejiler izlenmiştir.

\section{Reggio Emilia}

II. Dünya Savaşı sonrası Loris Malaguzzi tarafından İtalya'da geliştirilen Reggio Emilia yaklaşımı, aileleri eğitim paydaşları olarak görür. Ev ve toplum, çocukların hayatlarında önemli öğrenme ortamları olarak tanınmalıdır. Eğitimciler, ebeveynler ve çocuklar arasındaki eşgüdüm son derece değerlidir ve 'öğrenme grubu' kavramı Reggio Emilia yaklaşımının çok önemli bir yönüdür (Giudici, Rinaldi \& Krechevsky, 2001). Ebeveynler çocukların ilk ve sürekli eğitimcileridir. Uygulayıcı ve ebeveynlerin erken çocukluk ortamlarında beraber çalışmaları, çocukların gelişim ve öğrenmeleri üzerinde olumlu etkiye sahiptir. Rinaldi (1985), aile katılımı ile ilgili sunulan fırsatları, sınıf toplantıları, küçük grup toplantıları, bireysel ebeveyn öğretmen görüşmeleri, konulu toplantılar, bir uzmanla toplantı, çalışma oturumları, laboratuvar çalışmaları, tatiller ve kutlamalar olarak sıralamaktadır (Cited in. Şahin, 2017). Bennett (2001), ailelerin aynı zamanda öğrenme ortamlarında çeşitli düzenlemeler yaparak (bahçeye ağaç dikmek, sınıf için materyaller hazırlamak vb.) eğitim programına katılım gösterdiklerini ifade etmiştir. Yaklaşıma göre ebeveynlere, paydaş olarak saygı göstermenin arkasında yatan önemli mesajlar vardır. Ebeveynler kalıcı ve kapsamlı bir öğrenme ortamı sağlayarak çocukların öğrenme ve gelişimlerine olumlu katkıda bulunabilirler. Ebeveynler, çocuğunun bakım ve eğitimiyle ilgili her düzeyde karar vermede merkezi bir rol oynama hakkına sahiptirler. Ebeveynler ve eğitimciler arasındaki başarılı ilişkiler, çocukların eğitiminde faydalı ve uzun süren etkilere sahiptir. Bu yaklaşımda eğitimcilerin ebeveynlerin çocuklarına dair paylaşımlarını dikkate almaları önemlidir. Reggio Emilia yaklaşımında bir ebeveynin okula ilişkin ve okulun ebeveyne ilişkin neler bekleyebileceğini tanımlayan "Ebeveyn Hakları", ebeveynlerin okul yapısının bir bölümünde belirli bir rol oynamasından ziyade, okul yapısının bir parçası olmasının önemini anlatır. Okul, çocukları nasıl anladıklarını ve değerlendirdiklerini, ebeveynlere gösterme sorumluluğunun farkındadır (Thornton \& Brunton, 2009).

Öğretmenler özellikle program başlangıcında, ebeveynlerin çocukları tanımlamak için seçtikleri kelimeleri dikkatlice dinlerler. Öğretmenlerin ebeveynlerden alacakları bu bilgiler, çocuğun eğitim ortamına uyum sağlaması öğrenme deneyimlerinden verimli bir şekilde yararlanması için doğru ortamı ve desteği sağlamalarına yardımcı olacaktır. Çocuklar anaokuluna başlamadan önce ebeveynler ve çocuklar tanışma partilerine katılırlar ve okulları hakkında bilgi sahibi olurlar. Yaklaşımda öğretmenlerden kültürel farklılıkları göz önünde bulundurmaları ve tüm çocukların olumlu mesajlar alabileceği bir öğrenme ortamı yaratmaları beklenir. Bazı 
ebeveynler yaklaşımı anlamada zorlanabilirler, öğretmenler velilerin daha çok teşvik ve desteğe ihtiyaç duyabileceklerinin farkında olmalıdırlar. Öğretmenler velilere, sınıf ortamının düzeni, öğrenme ortamında neler yapıldığı ve bir günün nasıl geçtiği hakkında bilgi vermelidirler. Yaklaşımda dokümantasyon önemlidir. Gün sonunda çocuğunu almak için gelen ebeveynler, gün boyunca öğretmen tarafından çekilen fotoğraflar ve kaydedilen çocuk yorumlarının olduğu bir günlüğü incelerler. Böylelikle anne-baba, çocuğuyla gün içinde ne yaptıklarını konuşmaya başlayacaktır. Bunun yanında çocukların bireysel veya grup halinde ortaya çıkardıkları portfolyolar ya da diğer ürünler, geliş-gidiş zamanlarında ebeveynlere gösterilir ve belli aralıklarla eve gönderilir (Edwards, 2002). Yaklaşımda velilerin, çalışanların fotoğrafları, binanın planı ve tipik bir günün akışını içeren bir kimlik kartına sahip olmalarının, kendilerini ortamın bir parçası gibi hissetmelerine yardımcı olacağı ifade edilmiştir. Veliler sınıfa ilişkin proje ve konularla ilgili fikirleri tartışmak ve paylaşmak üzere öğretmenler, atölye eğitimcileri ve pedagoglarla grup toplantılarına katılırlar ve aynı zamanda erken çocukluk konseylerine katılarak merkezlerin yönetiminde rol oynarlar (Thornton \& Brunton, 2014).

\section{Yaratıcı Program (Creative Curriculum)}

Yaratıcı Program, 1979 yılında Amerika'da ortaya çıkmıştır. Bu programa göre, ev ve okul çocuğun iki önemli dünyasıdır. Çocuklar bu iki dünya arasında her gün köprü kurarlar. Eğer ev ve okul arasında olumlu ve saygılı bir iletişim kurulursa çocuk kendini güvende hisseder. Ancak aile ve okul ilgisizlik, anlayış eksikliği veya işbirliğindeki yetersizlik nedeniyle birbirlerinden ayrılırsa çocuk bundan olumsuz yönde etkilenir. Çocuğun eğitiminde ailenin rolüne inanan ve işbirliği ile çocuğun neler başarabileceğinin farkında olan bir öğretmen, ailelerle doğru bir ortaklık kurabilir. Yaratıcı Program, aileleri tanımak, aileleri karşılamak, ailelerle iletişim kurmak, çocuğun öğrenmesinde aileler ile ortaklık kurmak, ailelerin zorlandığı durumlarda onlara yol gösterici olmak gibi öğretmen-aile işbirliği için önemli olan beş başlığı ele almıştır. Programda, aileleri tanımak başlığı altında, farklı aile yapılarını, ebeveynlerin kişilik ve mizaç özelliklerini, ebeveynlerin eğitim düzeyi, sosyoekonomik durumu, sağlık problemleri gibi okul ile ilişkisini etkileyebilecek farklılıklarını ve ailenin sahip olduğu kültürel farklılıkları anlamanın önemine vurgu yapılmıştır. Aileleri tanımanın çocuğun ilerlemesi için bir ön koşul olduğu ve aileleri tanırken onları genellememek ve etiketlememek gerektiğine dikkat çekilmiştir.

Programa göre, aile ile kurulacak ilk iletişim çok önemlidir. Ailelerle ilk buluşma onları tanıma ve olumlu ilişkiler kurma açısından öğretmene büyük kazançlar sağlar. Ailelerle kurulacak ilk iletişim ev ziyareti ya da okula kayıt esnasında görüşme şeklinde olabilir. Okula kayıt sırasında ailelere ilişkin bilgi edinmek için ailelere formlar doldurtulabilir ya da görüşmelerde yönlendirilen sorular aracılığıyla velilerden bilgi toplanabilir. Kayıt esnasında özel yetenekleri ve ilgileri olan aileleri tespit etmek, sınıfta çocuklarla paylaşımda bulunmaları için yararlı olabilir. Programda ev ziyaretleri oldukça önemlidir. Aileler kendi ortamlarında okul ortamına göre daha rahattırlar. Senenin başında yapılan ev ziyaretleri, okul ortamında bulunmayan bir çocuk için okul ile ev arasında köprü oluşturmanın ilk yoludur. Programda, öğretmenlerin ziyaretten önce ailelere haber vererek bilgilendirmeleri ve zamanı kararlaştırmalarının önemi belirtilmiştir. Öğretmenler, aileleri yargılamak için değil onları tanıma ve ilişki kurma amacıyla gitmeli ve sorular sorarak aileleri kendileri hakkında konuşmaya teşvik etmelidirler. Programa göre, ailelerin karşılanması, ailelerin programa olan aidiyetleri için önemli bir noktadır. Sınıfta yaratılan ortam ve programı tanıtma, ailelere onların da sürece ait olduklarını ve oynayacakları bir rol olduğunu hissettirebilir. Çevre, olumlu mesajlar taşımalıdır. Öğretmen aileleri karşılama için hoş bir ortam oluşturabilir. Her aile için sınıf girişinde posta ve öneri kutuları ayarlanabilir. Ebeveynlere okumaları ve göz atmaları için kaynaklar önerilebilir. Program etkinliklerini güncellemek için bir duyuru panosu oluşturulabilir. Çocuklar bir programa ilk kez dâhil olduklarında aileler çocukların ne öğreneceğini merak ederler. Yaratıcı Program'da ebeveynler için "Okul Öncesi Eğitimi Ebeveyn Rehberi” yer almaktadır. Programın felsefesini ve çocuk için amaçlarını anlatan bu rehberde yer alan içerik ailelere kısaca açıklanır ve daha sonra okumaları istenir. Ailelere sınıf gezdirilerek, farklı ilgi alanları, günün nasıl geçtiği, okulun ilk gününe ilişkin beklentiler paylaşııı. Bununla beraber Yaratıcı Program'ın her bölümünün sonunda yer alan "Ailelere Mektup", çocukların ne yapacağını, öğretmenin çocukları nasıl desteklediğini ve ailelerin bu sürece evde nasıl yardımcı olacağını anlatır.

Yaratıcı Program'ın aile katılım boyutunun bir diğer önemli bileşeni ise ailelerle iletişim kurmaktır. Öğretmenler ve aileler arasındaki güven, zamanla gelişir ve olumlu ve saygılı bir çerçevede gerçekleşen deneyimlere bağlıdır. Diğer programlarda olduğu gibi Yaratıcı Programda da öğretmenler her gün ebeveynler ile gidiş-geliş zamanlarında resmi olmayan iletişim fırsatına sahiptir. Bunun yanında günlük veya haftalık bültenler, telefon görüşmeleri, e-posta, internet, sınıf web sitesi, teşekkür notları, günlükler, otomatik telefon mesaj sistemleri gibi resmi iletişim yolları da programda yer almaktadır. Ayrıca programda sadece ebeveynleri değil diğer aile bireyleri de programa dâhil olabilirler. Büyükanne ve büyükbabalar, ebeveynlerden daha fazla zaman 
ayrılabilir, sınıfta çocuklara kitap okuma, oyun öğretme, özel aktivitelere yardım etme gibi programa katılım gösterebilirler.

Programda aileler, öğrenme merkezlerine çeşitli düzenlemeler ya da eklemeler yaparak, kültürlerini paylaşarak (yemek pişirme etkinlikleri, sanatsal nesneleri tanıtma, şarkı öğretme, hikâye anlatımı vb.), meslek ya da bir yeteneği paylaşarak programa katılım gösterebilirler. Öğretmen bilgi ve programları paylaşmak için aileler ile toplantılar düzenler. Yapılan toplantılarda aileler de programa ilişkin değerlendirmelerini ifade ederler ve programın iyileştirmesine yönelik çalışmalara katkı sağlarlar. Bunların yanında öğretmen çeşitli sorunlar yaşayan ve stres altında olan ailelere çözüm yollarını gösterir ve aileler çözüm için kaynakların onlara açık olduğunu bilirler (Dodge, Colker \& Heroman, 2008).

\section{Te Whāriki}

Te Whāriki programı 1996 yılında Yeni Zelanda Milli Eğitim Bakanlığı tarafından geliştirilmiştir. Yeni Zelanda'nın erken çocukluk felsefesinde işbirliği temel bir kavramdır. Te Whāriki ebeveynlerin merkezdeki konumunu vurgular. Bu program aileyi erken çocukluk eğitiminin ortaklarından biri olarak görür. Bu program aile, okul ve çevre arasındaki bağlantıyı güçlü tutarak, çocukların bilgi dağarcıklarını genişletmeyi amaçlar (Zhanq, 2013). Te Whāriki'de erken çocukluk hizmetleri, öğretmenler ve ebeveynler tarafından yönetilen oyun merkezli toplum temelli anaokullarını içermektedir. Te Whāriki'ye göre çocuklar, kültürleri, bilgi birikimleri ve içlerinde yaşadıkları toplum benimsendiğinde ve hayatlarındaki yetişkinler iş birliğiyle hareket ederek onları desteklediklerinde öğrenir ve gelişirler. Öğretmenin ve ailelerin anlamlı ilişkiler geliştirmesi, çocukların gelişimi için birbirlerinin istek ve beklentilerine saygı duymaları önemlidir. Çocukların öğrenme ve gelişimleri, kültürel açıdan uygun iletişim yolları kullanıldığında ve ebeveynlerin, kişilerin, toplumun müfredata katılımları sağlandığında kolaylaşır. Programda, kültürel çeşitliliğe ve farklı aile yapılarına saygı duyulur. Öğretmen bu yapıları programa uygun şekilde yansıtabilmek için çocukların aileleri hakkında bilgi sahibi olmalıdır.

Çocukların ilk yıllarında başarılı bir geçiş için ailenin nasıl karşılandığı önemlidir. Ebeveynler ve öğrenciler memnuniyetle karşılanırlar. Paylaşılan bir öğle yemeği, gezi veya açık hava etkinlikleri gibi aktiviteler, ebeveyn ve öğretmenlerin bir araya gelmesini sağlar. Öğretmenlerin, çocukların okul ortamına geçişini desteklemek için ebeveynlerle yakın işbirliği içerisinde çalışması ve çocukların değişen ilgi alanları, ihtiyaçları ve gelişimleri hakkında düzenli olarak iletişim kurmaları esastır. Programda, öğretmenlerin beslenme, çocukların fiziksel aktivitesi ve büyümesi konularına yönelik ebeveynler ile paylaşabilecekleri bir referans kütüphanesi bulunmaktadır. Programda fotoğrafları, çocukların ürünleri, öğretmenin gözlem kayıtlarını ve çocukların öğrenme hikâyelerini içeren portfolyolar, ebeveynlere çocuklarının öğrenme süreci hakkında fikir edinmeleri, kendi gözlem ve önerileri ile sürece katkıda bulunma fırsatı sunar. Programlar planlanırken çocukların kaliteli eğitim ve hizmet almaları için erken çocukluk hizmet sağlayıcılarının, öğretmenlerin ve ebeveynlerin ihtiyaçları ve görüşleri dikkate alınır (New Zeland Ministry of Education, 1996).

\section{Tartışma, Sonuç ve Öneriler}

Erken çocukluk döneminde aile katılımının, çocuğun tüm gelişim alanlarına katkıda bulunduğu, çocuğun okula hazırbulunuşluğunu desteklediği, olumlu davranışları arttırdığı ve çocuğun ileriki okul başarısına katkıda bulunduğu görülmektedir (Epstein, 2011; Henderson et al. 2007; . Rimm-Kaufman et al. 2003; Sheldon, 2003). Aile katılımının çocuk için önemli çıktıları göz önünde bulundurulduğunda, aile katılımının, başarılı ve etkili bir programın önemli bir boyutu olduğu anlaşılmaktadır. Genel olarak incelendiğinde, programların felsefe ve prensipleri doğrultusunda aile katılımı boyutunda küçük farklılıklar yer alsa da, incelenen bütün programların aile katılımını önemsedikleri ve programlarının önemli bir boyutu olarak ele aldıkları görülmektedir. Bütün programlarda ailelere yönelik toplantılar, bireysel görüşmeler, çocukların fotoğraflarını, ürünlerini, öğretmenin gözlem kayıtlarını ve çocukların öğrenme hikâyelerini içeren portfolyo paylaşımı gibi aile-okul arasındaki iletişim ve işbirliğini güçlendirecek aile katılım çalışmaları yer almaktadır. Programların amaçları, programların yaklaşım ve felsefelerine göre değişse de, bütün programlar aileyi çocuğun ilk ve en önemli eğitimcisi olarak kabul eder (Temel ve Toran, 2017).

Illk Yıllar Programı'nda ailelerin sistemi tanımaları ve okulu her anlamda desteklemelerinin üzerinde durulmuştur. Programa göre ailelerin programı tanıyarak ve evde de benzer yaklaşımlar geliştirmeleri programın işleyişi açısından çok önemlidir. Okulda sorgulayan, analiz eden ve sonuca varan öğrenci, evde de bu becerileri göstererek karar alma süreçlerine dâhil olur. Yıl sonunda, çocukların çalışmalarını paylaştıkları sergiler ise Illk Yıllar Programı aile katılımı çalışmalarının önemli bir boyutudur (Çamlıkaya, 2007; IBO, 2002). Montessori programının aile katılımı boyutu incelendiğinde, çocukların akademik, fiziksel ve sosyal gelişimleri hakkında ya da gün içindeki durumları ile ilgili ailelerle düzenli aralıklarla iletişim kurmak önemli bir nokta olarak görülmektedir. Montessori yaklaşımında aileleri programa ilişkin bilgilendirmek sınıftaki farklı yaşların 
bütünleştirilmesini kolaylaştırır, akademik becerilerin gelişiminde kolaylıklar ve ailelerin okula karşı olumlu tutumlar geliştirmesini sağlar. Montessori okulları, okul-aile arasında nitelikli ilişkiler kurmayı amaçlamıştır. Bu amaçla yapılan aile katılımı çalışmaları arasında düzenli toplantılar, okul gazetesi, özel günler, aile eğitim programları, yeni aile kabulleri, açık yönetim kurulu toplantıları, yıllıklar, aile dernekleri ile işbirliği yapmak yer almaktadır (Danişman, 2012; Isaacs, 2012; Korkmaz, 2005; Temel \& Toran 2017). Reggio Emilia yaklaşımında bir ebeveynin okula ilişkin ve okulun ebeveyne ilişkin neler bekleyebileceğini tanımlayan "Ebeveyn Hakları", ebeveynlerin okul yapısının bir bölümünde belirli bir rol oynamasından ziyade, okul yapısının bir parçası olmasının önemini anlatır. Yaklaşım dokümantasyonun üzerinde durur. Dokümantasyon yoluyla ebeveynler, gün boyunca öğretmen tarafından çekilen fotoğraflar ve kaydedilen çocuk yorumlarının olduğu bir günlük sayesinde çocuklarının okulda neler yaptıkları ile ilgili fikir sahibi olurlar (Edwards, 2002; Thornton \& Brunton, 2014). Yaratıcı Program da aileleri çocuklarının gelişimlerini anlamak, değerlendirmek, desteklemek için çeşitli yöntemler kullanarak eğitimin içerisine katmaktadır. Aileler, program için materyal sağlama, kültürel paylaşımlar yapma (kültürel materyal, giysi, yemek, şarkı, hikâye, resim paylaşımı vb.), mesleki veya yeteneklere yönelik paylaşımda bulunma, bir çalışmaya katılma ve programın oluşturulma aşamasına katılma konusunda sorumluluk almaktadırlar (Dodge et al. 2008). Te Whāriki programı da diğer programlar gibi aileyi erken çocukluk eğitiminin ortaklarından biri olarak görür. Te Whāriki'ye göre çocuklar, kültürleri, bilgi birikimleri ve içlerinde yaşadıkları toplum benimsendiğinde ve hayatlarındaki yetişkinler iş birliğiyle hareket ederek onları desteklediklerinde öğrenir ve gelişirler. Programda, kültürel çeşitliliğe ve farklı aile yapılarına saygı duyulur (New Zealand Ministry of Education, 1996; Zhanq, 2013).

Program ve yaklaşımlar bir arada değerlendirildiğinde, Reggio Emilia ve Yaratıcı Program'ın ortak özellikleri arasında, önemle durulan ev ziyaretleri, ailelerin karşılanması ve ailelerin sınıfta çeşitli düzenlemeler yaparak öğrenme sürecine katkıda bulunmaları yer almaktadır. Okulda gerçekleştirilen deneyim ve etkileşimlerin ailelerle paylaşıması tüm yaklaşımlarda yer alsa da, Reggio Emilia yaklaşımında dökümantasyon bir adım daha öne çıkarken; İlk Yıllar Programında ise yıl sonu sergileri öne çıkmaktadır. Illk Yıllar Programı ve Montessori yaklaşımı, programın verimli işlemesi için ailelerin programı anlamalarını önemsemektedirler. Kültürel farklııılar açısından bakıldığında, Reggio Emilia, Yaratıcı Program ve Te Whāriki'de çocukların programlarda en üst düzey gelişim ve ilerlemeyi sağlayabilmeleri için ailelerin kültürel yapılarının eğitimciler tarafından kabul edilmesi ve ailelerin bu anlamda olumlu karşılanmasına önem verilmiştir.

Okullar kendi eğitim programlarını oluştururken farklı erken çocukluk eğitim program ve yaklaşımlarının aile katılımı çalışmalarını kullandıklarında programlarındaki kalite ve verim artacaktır. Bu bağlamda nitelikli bir okul öncesi eğitim programının aile katılım boyutunu oluşturmak için tüm paydaşlar işbirliği içinde çalışmalıdır. Program geliştiricilerin ve eğitimcilerin farklı erken çocukluk eğitim program ve yaklaşımlarının aile katılımı çalışmalarını detaylı inceleyerek kendi kültürlerine, çocuklarına ve ailelerine uygun olan çalışmaları programlarına katmaları gerekmektedir. Okul ve eğitimcilere bu konuda gereken alt yapı, donanım sağlanmalı ve ülkelerin eğitim bakanlıklarının karar vericileri ve kanun koyucuları tarafından ülkelerin eğitim politikalarında yasal düzenlemelerin yapılması gerekmektedir. Kaliteli erken çocukluk eğitim programlarının geliştirilmesi, okul, aile ve toplum işbirliğinin etkili bir şekilde uygulanması ile desteklenerek ülkelerin eğitim politikalarını güçlü kılmalıdır. Dünyada erken çocukluk eğitimi programları, çocuğun ailesi ve kültürü ile birlikte ele alınmalı, ailenin programa etkin olarak katılımı sağlanmalı, toplumla iç içe olmayı başaran sosyal politikalar bünyesinde programlar planlanmalı ve uygulanmalıdır. Nitelikli aile katılımı çalışmaları sayesinde mutlu, ruh ve beden sağlığı yerinde olan, adil, sorumluluk sahibi, eşit eğitim fırsatları olan çocuklar ve dolayısıyla sağlıklı, mutlu, üretken aileler oluşur. Bu aileler de toplumun güçlenmesi ve kalkınmasında önemli katkılar sağlarlar. 


\section{References}

Arı, M. (2003). Türkiye'de erken çocukluk eğitimi ve kalitenin önemi. In M. Sevinç (Ed.), Erken çocuklukta gelişim ve eğitimde yeni yaklaşımlar (pp. 31-36). İstanbul: Morpa.

Aslan, D. (2005). Okul öncesi eğitimde Reggio Emilia yaklaşımı. Çukurova Üniversitesi Sosyal Bilimler Enstitüsü Dergisi, 14(1), 75-84.

Bennett, T. (2001). Reactions to visiting the infant-toddler and preschool centers in Reggio Emilia, Italy. Early Research and Practice, 3(1). Retrieved from https://archive.org/details/ERIC_ED453001.

Çamlıkaya, Ş. E. (2007). A close look into the IB PYP programme and a sample appiıcatıon from the IB PYP curriculum of a primary school that implements the Turkish natıonal curriculum. Unpublished master's thesis, Yeditepe University, i̇stanbul.

Danişman, Ş. (2012). Montessori yaklaşımına genel bir bakış ve eğitim ortamının düzenlenmesi. Eğitimde Politika Analizi Dergisi, 1(2), 85-113.

Demirel, Ö. (2005). Kuramdan uygulamaya eğitimde program geliştirme. Ankara: Pegem.

Dodge, D. T., Colker, L. J. \& Heroman, C. (2008). The creative curriculum for preschool (College Edition). Washington DC: Teaching Strategies.

Düşek, G. \& Dönmez, B. (2012). Türkiye'de yayımlanan okul öncesi eğitim programları. Mesleki Bilimler Dergisi, $1(1), 68-75$.

Edwards, C. P. (2002). Three approaches from Europe: Waldorf, Montessori, and Reggio Emilia. Early Childhood Research \& Practice, 4(1). Retrieved from https://ecrp.uiuc.edu/v4n1/edwards.html.

Epstein, J. L. (2011). School, family, and community partnerships: Preparing educators and improving schools. Westview Press.

Erkan, S. (2015). Aile ve aile eğitimi ile ilgili temel kavramlar. In F. Temel (Ed.), Aile eğitimi ve erken çocukluk eğitiminde aile katılım çalışmaları (pp. 3-48). Ankara: Anı.

Fink, A. (2009). Conducting research literature reviews: From the Internet to paper. CA: Sage.

Giudici, C., Rinaldi, C. \& Krechevsky, M. (Eds.) (2001) Making learning visible: children as group and individual and group leaders. Reggio Emilia Italy: Reggio Children.

Güler, T. \& Yaltırık, İ. (2011). Erken çocukluk eğitiminde İlk Yıllar Programı́nın öğretmen görüşleri ile incelenmesi. Eğitim ve Bilim, 36(160), 266-280.

Henderson, A. T., Mapp, K. L., Johnson, V. R. \& Davies, D. (2007). Beyond the bake sale: The essential guide to family-school partnerships. New York: New Press.

IBO (2002). School's guide to the Primary Years Programme. Geneva: International Baccalaureate Organization.

IBO (2014). The International Baccalaureate Primary Years Programme (PYP) in Victorian Government Primary Schools, Australia, Final Report. Retrieved from https://www.ibo.org/globalassets/publications/ibresearch/pyp/pypinaustraliafinalreport.pdf.

Isaacs B. (2012). Understanding the Montessori approach: Early years education in practice. New York, NY: Routledge.

İnan, H. Z. (2012). Okul öncesi eğitimde çağdaş yaklaşımlar: Reggio Emilia yaklaşımı ve Proje yaklaşımı. Ankara: Anı.

Karip, K. \& Köksal, K. (1996). Etkili eğitim sistemlerinin geliştirilmesi. Eğitim Yönetimi, 2(2), 245-257.

Korkmaz, H. E. (2005). Montessori Method and Montessori schools: Investigation Montessori schools in Turkey in terms of management and finance. Unpublished master's thesis, Marmara University, İstanbul.

Marcon, R. A. (1999). Positive relationships between parent school involvement and public school intercity preschoolers' development and academic performance. School Psychology Review, 28(3), 395-412.

Morrison, M. A. (2004). Tips on scientific writing. Retrieved from https://www.nhn.ou.edu/ morrison/Teaching/ WritingTips.pdf.

Mutlu, B., Ergişi, A., Bütün-Ayhan, A. \& Aral, N. (2012). Okul öncesi dönemde Montessori Eğitimi. Ankara Sağlık Bilimleri Dergisi, 1(3), 113-128.

New Zealand Ministry of Education. (1996). Te Whāriki early childhood curriculum. Wellington: Learning Media Limited. Retrieved from https://www.education.govt.nz/assets/Documents/Early-Childhood/te-whariki.pdf.

Oğuz, V. \& Köksal-Akyol, A. (2006). Çocuk eğitiminde Montessori yaklaşımı. Çukurova Üniversitesi Sosyal Bilimler Enstitüsü Dergisi, 15(1), 243-256.

Reynolds, A. J. (1998). Developing early childhood programs for children and families at risk: Research-based principles to promote long-term effectiveness. Children and Youth Services Review, 20(6), 503-523.

Rimm-Kaufman, S. E., Pianta, R. C., Cox, M. J. \& Bradley, R. H. (2003). Teacher-rated family involvement and children's social and academic outcomes in kindergarten. Early Education and Development, 14(2), 179-198. 
Sheldon, S. B. (2003). Linking school-family-community partnerships in Elementary schools to student achievement on state tests. Urban Review, 35(2), 149-165.

Şahin, F. (2017). Reggio Emilia yaklaşımı. In F. Temel (Ed.), Erken çocukluk eğitiminde yaklaşımlar ve programlar (pp. 445-477). Ankara: Vize.

Temel, F., Aksoy, A. B. \& Kurtulmuş, Z. (2015). Erken çocukluk eğitimde aile katlımı çalışmaları. In F. Temel (Ed.), Aile eğitimi ve erken çocukluk eğitiminde aile katılım çalışmaları (3rd ed.) (pp. 327-362). Ankara: Anı.

Temel, Z. F. \& Toran, M. (2017). Montessori eğitim yöntemi. In F. Temel (Ed.), Erken çocukluk eğitiminde yaklaşımlar ve programlar (pp. 141-190). Ankara: Vize.

Thornton, L. \& Brunton, P. (2009). Understanding the Reggio approach: early years education in practice. New York, NY: Routledge.

Thornton, L. \& Brunton, P. (2014). Bringing the Reggio approach to your early years practice. New York, NY: Routledge.

Tuncer, B. (2015). Okul öncesi eğitimdeki çağdaş yaklaşımların incelenmesi ve MEB okul öncesi programıyla karşılaştırılması. International Journal of Field Education, 1(2), 39-58.

Van Voorhis, F. L., Maier, M. F., Epstein, J. L., \& Lloyd, C. M. (2013). The impact of family involvement on the education of children ages 3 to 8: A focus on literacy and math achievement outcomes and social-emotional skills.

Retrieved

from https://www.mdrc.org/sites/default/files/The_Impact_of_Family_Involvement_FR.pdf.

Weed, D. L. (1997). Methodologic Guidelines for Review Papers. Journal of the National Cancer Institute, 89(1), 6-7.

Weiss, K. (2013). Teachers' perspectives on assessment of the learner profile attributes in the primary years programme. Unpublished master's thesis, Bilkent University, Ankara.

Yaşar-Ekici, B. (2015). Okul öncesi eğitimde uygulanan çocuk merkezli yaklaşımların kuramsal temel, eğitim ortamı ve öğretmenin rolü açısından karşılaştırılması. Akademik Sosyal Araştırmalar Dergisi, 3(12), $192-212$.

Zhang, Q. (2013, November). Why do New Zealand parents become involved in their children's early childhood education? Paper presented at the NZARE Conference \& Annual Meeting, Hamilton, New Zealand. 
